\title{
ESR1 Gene
}

National Cancer Institute

\section{Source}

National Cancer Institute. ESR1 Gene. NCI Thesaurus. Code C38349.

This gene is involved in ligand-activated transcriptional activity. 